\title{
Waste as a source for district heat production and greenhouse gas reduction: a case study
}

\author{
S. Vares ${ }^{1}$, K. Klobut ${ }^{1} \&$ A. Itänen ${ }^{2}$ \\ ${ }^{1}$ VTT, Finland \\ ${ }^{2}$ Ekokem, Finland
}

\begin{abstract}
In the EU's waste strategy, the order for sustainable waste actions is: reduction, reuse and recycling. Recovery has recently been added as a fourth action, and it is applied to the waste types that cannot be reused or recycled. Thus, recovery remains the last option before final landfilling. The annual amount of municipal waste from households in Finland is 2.5 million tons. Waste collection and utilization is organized relatively well, but still 1.1 million tons are disposed of to landfill. A recent survey on mixed waste quantity and quality showed that almost $65 \%$ of its content is bio-based. Energy recovery from this waste in combined incineration plants for district heat and electricity (CHP) may serve as an additional measure for greenhouse gas reduction in local communities. Since buildings are responsible for approximately $40 \%$ of energy consumption, it is important to reduce energy consumption. In Finland, due to the long heating season, the energy production method and heat source are extremely important for greenhouse gas reduction. This paper discusses energy recovery from waste in a case study of a new residential area in southern Finland. All the buildings fulfil current Finnish energy requirements and represent typical wooden frame construction with rendering façades. It is assumed that the households will be connected to the local district heat system, in which heat is produced partly in gasdriven heat plants and partly in a municipal waste incineration plant. We show that energy recovery from waste should not be underestimated, because it is a valuable means of greenhouse gas reduction, especially in local communities.
\end{abstract}

Keywords: municipal waste, district heat production, energy efficient buildings, greenhouse gas reduction, carbon footprint. 


\section{Introduction}

It is claimed that building stock in EU 27 is responsible for about $40 \%$ of total energy consumption and $36 \%$ of greenhouse gas emissions. To reduce such a high energy consumption, the EU adopted the Energy Performance of Buildings Directive 2010/31/EU (EPBD) [1]. The directive requires that, by 2021, all new buildings are so-called 'nearly zero-energy buildings'. The requirement also considers alternative energy systems for new buildings, such as renewable energy sources, district heating and cooling, but also CHP production. The Building Code [3] in Finland has recently been updated and is accompanied by ordinances to implement the requirements of the directive and impose energy efficiency requirements for new buildings.

In Finland, energy efficiency in new construction is ensured by setting a limit to the total energy demand. This demand should be calculated and expressed as an E-value that also takes into account purchased energy sources (Finnish Ministry of Environment order 4/13, 2012 [2]). In the early design stages, the reference U values and heat recovery of the ventilation system as well as other reference values given in the Building Code [3] should be used in order to ensure that the E-value requirement will be achieved.

In Finland, 95\% of residential multi-storey buildings and the majority of office buildings are connected to district heating networks. In the case of single family buildings, attached and detached buildings, only $7 \%$ are heated with district heat. Altogether, district heat has almost a 50\% share in the Finnish heating market. The main fuel sources in district heat production are coal, natural gas, wood and biobased fuels and peat [4]. Heat produced in waste incineration plants has so far played a minor role in the Finnish heat market, but new capacity will be launched in the coming years.

The annual amount of municipal waste from households in Finland is 2.5 million tons. Waste collection and utilization is organized relatively well, but 1.1 million ton is still disposed to landfill [5]. Waste from household and construction is not considered to be a renewable source, but as a majority of these materials contain carbon and thus heat value, energy recovery is an option for energy and heat producers.

The life cycle approach in building assessment and waste-to-energy management is a powerful approach for accounting for the environmental burdens of those integrated systems. Environmental burdens in this study were assessed for greenhouse gas emissions, and quantified for one value as a carbon footprint (CF). By definition, $\mathrm{CF}$ is the overall amount of carbon dioxide $\left(\mathrm{CO}_{2}\right)$ and other greenhouse gas (GHG) emissions (e.g. methane, nitrous oxide, etc.) associated with a product along its supply-chain, use and end-of-life recovery and disposal [6].

\section{Description of the case study}

This paper discusses energy recovery from municipal waste in a CHP incineration plant as a case study of a new residential area in Southern Finland. The life cycle approach is chosen, and a carbon footprint assessment is carried out for one 
detached single-family building, which has a typical building structure used in Finland. This assessment is then enlarged to cover the whole of one new residential area, which contains 29 family buildings. For simplicity's sake, it is assumed that all the buildings have the same building design and meet current Finnish energy requirements (DH 2012). For comparison, the improved energy efficiency case is also shown (DH 2021).

A district heating network serves the area by providing the heat for space heating and hot water. It is considered that all households will connect to the district heat system. Local district heat is produced from gas-driven heat plants and a municipal waste incineration plant. The comparison is made for the case where heat is produced from a separate, gas-driven plant, which would be the case without a waste incineration plant nearby.

This assessment covers the building life cycle stages (according to EN 15804): production stage and use stage [7]. The production stage covers raw material supply (A1), transportation (A2) and manufacturing (A3), and the use stage covers an operational energy use (B6).

\subsection{Carbon footprint for detached building (production stage)}

Life cycle assessment is carried out for the typical detached building, with a wooden frame construction and a rendering façade. In this case, the building is a two-storey building with a living area of $159 \mathrm{~m}^{2}$. Assessment was carried out using VTT's Carbon Footprint tool, Ilmari [8]. The results are presented in Table 1 for two energy efficiency building options - for current energy efficiency requirement DH 2012, and for improved requirement DH 2021. Assessment covers the building production stages $\mathrm{A} 1-\mathrm{A} 3$.

Table 1: $\quad$ Material quantities and carbon footprint (CF) for current detached building (DH 2012) and improved energy efficiency (DH 2021).

\begin{tabular}{|c|c|c|c|c|c|}
\hline \multirow[t]{2}{*}{ Structure type } & \multirow[t]{2}{*}{ Material types } & \multicolumn{2}{|c|}{ DH 2012} & \multicolumn{2}{|c|}{ DH 2021} \\
\hline & & $\begin{array}{l}\text { Material, } \\
\quad \mathrm{kg}\end{array}$ & $\begin{array}{l}\mathrm{CF} \\
\mathrm{kg}\end{array}$ & $\begin{array}{l}\text { Material, } \\
\mathrm{kg}\end{array}$ & $\begin{array}{l}\mathrm{CF} \\
\mathrm{kg}\end{array}$ \\
\hline $\begin{array}{l}\text { Exterior wall, } \\
165 \mathrm{~m}^{2}\end{array}$ & \begin{tabular}{|l|} 
Rendering, concrete, wood \\
structure, gypsum boards, \\
mineral wool, veneer \\
\end{tabular} & 14,318 & 4,318 & 17,608 & 6,096 \\
\hline $\begin{array}{l}\text { Partition wall, } \\
299 \mathrm{~m}^{2}+32 \mathrm{~m}^{2}\end{array}$ & $\begin{array}{l}\text { Wooden frame gypsum board, } \\
\text { walls with and without insulation }\end{array}$ & 8,976 & 3,502 & 8,976 & 3,502 \\
\hline Basement, $43 \mathrm{~m}$ & Concrete, insulation & 53,223 & 11,059 & 53,223 & 11,059 \\
\hline $\begin{array}{l}\text { Base floor, } \\
90 \mathrm{~m}^{2}\end{array}$ & $\begin{array}{l}\text { Concrete polystyrene, gravel and } \\
\text { sand }\end{array}$ & 108,755 & 5,565 & 109,120 & 6,797 \\
\hline $\begin{array}{l}\text { Intermediate } \\
\text { floor, } 69 \mathrm{~m}^{2}\end{array}$ & $\begin{array}{l}\text { Glued laminated beam, veneer, } \\
\text { gypsum board, mineral insulation }\end{array}$ & 7,424 & 2,997 & 7,424 & 2,997 \\
\hline $\begin{array}{l}\text { Roof, } \\
89 \mathrm{~m}^{2}\end{array}$ & $\begin{array}{l}\text { Bitumen roofing, veneer, wooden } \\
\text { trusses, mineral-wool, gypsum } \\
\text { board }\end{array}$ & 4,291 & 1,539 & 4,466 & 1,576 \\
\hline $\begin{array}{l}\text { Windows, } 43 \mathrm{~m} 2 \text {, } \\
\text { doors } 11 \mathrm{~m}^{2}\end{array}$ & $\begin{array}{l}4 \text { glass wood/al windows, wooden } \\
\text { doors and stairs }\end{array}$ & 2,466 & 2,466 & 2,466 & 2,466 \\
\hline Total & & 200,893 & 31,446 & 204,830 & 34,494 \\
\hline
\end{tabular}




\section{Municipal solid waste}

\subsection{Composition, properties and collection rate}

According to Finnish waste regulations, $50 \%$ of the municipal waste by weight should be recycled by 2016 [9]. This is met with a separate national waste collection requirement for paper, cardboard, glass, metal, plastic and bio waste which is valid for industry, service and other businesses, waste holders and municipalities. Waste fractions which come from household collection are source separated recyclables and mixed waste. For better waste management and utilization, the properties of the mixed waste need to be known.

A recent study by Pulkkinen and Sinisalo [10] shows that household waste composition and quantity are affected by many factors, the main one being the age distribution of the residents, building type, household size, and number of free magazine distributions. In this study, an annual mixed waste production was 176 $\mathrm{kg} /$ per capita, and this contained $65 \%$ of bio-based fractions, $26 \%$ of other substances suitable for incineration, and $9 \%$ of inert waste. However, according to information from the Statistics Finland, mixed waste contains only $50 \%$ of biobased fractions, having a caloric value of $10 \mathrm{GJ} / \mathrm{t}$ and a $\mathrm{CO}_{2}$-emission coefficient of $40 \mathrm{t} / \mathrm{TJ}(144 \mathrm{~g} / \mathrm{kWh})$ [11]. The IPCC report shows [12] that $\mathrm{CO}_{2}$ emission for $100 \%$ of anthropogenic, non-bio based waste fraction is in the range of 73.3-121 $\mathrm{t} / \mathrm{TJ}$. If the Statistics Finland-proposed $\mathrm{CO}_{2}$ value is calculated for $100 \%$ of the non-bio based fraction, then the emission coefficient will be $80 \mathrm{t} / \mathrm{TJ}$, and this fits the range proposed by IPCC.

As no dedicated waste composition study was conducted for the case area considered here, uncertainty remains about the waste compounds, especially the amount of bio-based substances and total heating value. It is considered to use the mixed waste default values from Statistics Finland. However, the waste collection distances and amounts, $192 \mathrm{~kg}$ per capita, are based on area collection data obtained from a local waste management company.

\subsection{Energy from waste}

Incineration is the process of combusting direct waste so as to produce energy for district heating or, in the combined heat and power process (CHP), also to generate power. There are also other possibilities for recovering energy from waste, e.g. gasification or the production of fuels for combustion; production of biogas or different type of recovered fuels; however, these other methods were excluded from this assessment.

The waste incineration company, Ekokem, recovers energy from municipal, solid mixed waste but also from hazardous waste in conversion into heat and power. For this study, the energy production is modelled only for the use of municipal waste and for Power plant 1 . The model contains a three-year average production (2010-2012) and also the production year 2013 but also purchase of municipal waste with an impact on waste collection and transport. During the years 2010-2012 the production technology was improved. The main 
improvement was made in 2013 when electricity was produced for the grid and heat recovery from the flue gas was taken into use.

As the CHP incineration process produces multi-products, such as power and heat/steam, there is a challenge in allocating emissions between these products. The selection of an allocation method typically has a significant impact on the results [12]. In this waste-to-energy assessment, the so called benefit distribution method is used, where the primary energy consumption of combined heat and power production is allocated to district heat and electricity in proportion to the efficiencies of alternative (separate) production.

A contradiction exists between continuous waste generation and the main heating need occurring in the heating period. It is seen as increased heat loss and carbon footprint in summer time (Figures 1 and 2).

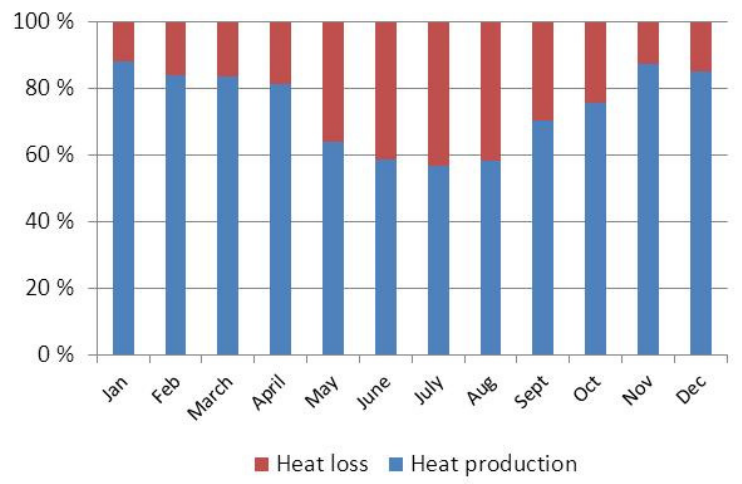

Figure 1: Energy production share between heat production and heat loss in a CHP incineration plant.

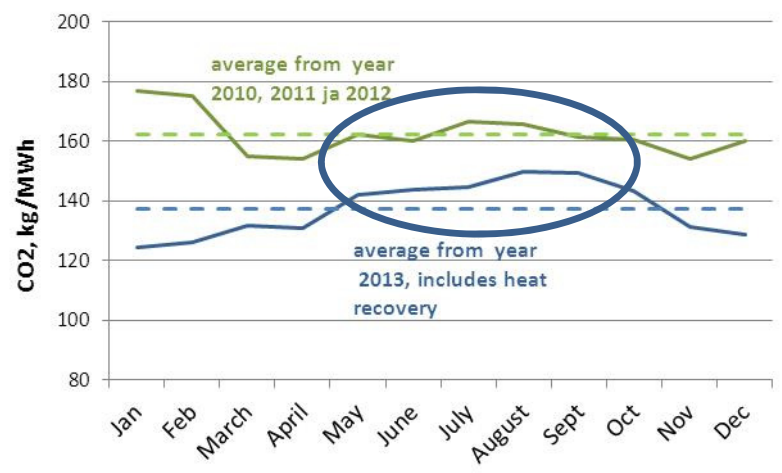

Figure 2: Carbon footprint for the heat production in a CHP plant from municipal waste combustion and acquisition. 


\subsection{Credits from waste utilization to energy}

One main credit in waste utilization to energy is the savings in fossil fuels that would otherwise be used. For example, marginal electricity production could be based on a coal firing technique where $\mathrm{CO}_{2}$ emissions are nearly $900 \mathrm{~g} / \mathrm{kWh}[13]$, or in the other region for example a gas-driven heat plant $\left(\mathrm{CO}_{2}\right.$ is $\left.233 \mathrm{~g} / \mathrm{kWh}\right)$ works as marginal heat source.

Waste incineration plants also work in the material recovery field annually producing recovered aluminium and other ferrous metals. The amount of virgin material saving could be calculated as the extraction of virgin material and recycled material impacts. For aluminium savings, this could be $5126-518=4608 \mathrm{~kg}$ of $\mathrm{CO}_{2} / \mathrm{Mg}$ or for Fe it could be $1820-595=1225 \mathrm{~kg}$ of $\mathrm{CO}_{2} / \mathrm{Mg}$ [14]. Since then, the impacts from $\mathrm{Al}$ and $\mathrm{Fe}$ have decreased, but the impact is still significant. In this assessment, it is considered that raw material saving from recovered metals is $790 \mathrm{~g} / \mathrm{kg}$ recovered.

Municipal waste utilization prevents equivalent gas releases to the atmosphere in the case of uncontrolled landfilling. In anaerobic decomposition, the organic waste fractions start to produce gas, mainly methane and carbon dioxide. If we know the carbon content of organic waste fractions, the amount of $\mathrm{CH}_{4}$ can be estimated. According to the waste management company, it is considered that one waste ton in landfill causes $100-200 \mathrm{~m}^{3}$ gas releases, in which $50 \%$ is $\mathrm{CH}_{4}$. It should be noted that methane has a 25 times stronger effect on greenhouse gas formation than $\mathrm{CO}_{2}$.

\subsection{Energy production potential from municipal waste}

In 2013, Finland has 6 incineration plants with a capacity of more than 700,000 tons. Most of them are fire grate plants, except for one where the gasification technology is used. According to the Finnish Solid Waste Association, the capacity of the existing and already designed incineration plants will in the near future be more than 1.4 million tons [15]. The recovered energy yield to heat and electricity varies according to the combustion technique, but the total energy efficiency rate in CHP plant is approx. 85\%. The prediction for the heat and electricity production from solid mixed waste for the year 2016 is respectively $2038 \mathrm{GWh}$ and $676 \mathrm{GWh}[16]$.

\subsection{Building energy simulation and carbon footprint}

Energy simulation for the buildings in this study was performed by using IDA, Indoor Climate and Energy software [17]. According to the Finnish building code, D3, the energy consumption indicator, E-value, for this type of building should not exceed the value $160 \mathrm{kWh} / \mathrm{m}^{2}$, and this was also met for the district heat case. Annual energy consumption, E-value and carbon footprint calculated for two energy efficiency building variants are given in Table 2. The carbon footprint value, used for a gas-driven heat plant, was $233 \mathrm{~g} / \mathrm{kWh}$ (based on ELCD data for acquisition [18] and Finnish statistic data [11] for combustion) and for electricity was $330 \mathrm{~g} / \mathrm{kWh}$ (based on a Finnish 4-year average, including net import). 
Table 2: Annual energy consumption and carbon footprint for current (DH 2012) and energy efficient detached building (DH 2021) (space heating and domestic hot water demands are covered by gas-driven district heat plant).

\begin{tabular}{|l|c|c|c|c|c|c|}
\hline & \multicolumn{3}{|c|}{ DH 2012 gas* } & \multicolumn{3}{c|}{ DH 2021 gas** } \\
\hline & $\mathrm{kWh}$ & $\mathrm{kWh} / \mathrm{m}^{2}$ & $\mathrm{CF}, \mathrm{kg}$ & $\mathrm{kWh}$ & $\mathrm{kWh} / \mathrm{m}^{2}$ & $\mathrm{CF}, \mathrm{kg}$ \\
\hline Lighting & 1,145 & 7 & 378 & 1,146 & 7 & 378 \\
\hline Cooling & 715 & 4 & 236 & 400 & 2 & 132 \\
\hline Ventilation & 1,388 & 8 & 458 & 753 & 5 & 248 \\
\hline $\begin{array}{l}\text { Building } \\
\text { electricity }\end{array}$ & 2,715 & 16 & 896 & 2,716 & 16 & 896 \\
\hline $\begin{array}{l}\text { Outdoor lighting, } \\
\text { car heating }\end{array}$ & 385 & 2 & 127 & 385 & 2 & 127 \\
\hline Heating & 17,722 & 106 & 4,129 & 6,804 & 41 & 1,585 \\
\hline Hot water & 4,213 & 25 & 982 & 5,047 & 30 & 1,176 \\
\hline Total, electricity & 6,348 & 38 & 1,479 & 5,400 & 32 & 1,258 \\
\hline Total, district heat & 21,935 & 131 & 5,111 & 11,851 & 58 & 2,761 \\
\hline E-value & & 156 & & & 105 & \\
\hline
\end{tabular}

\section{Results for the case area}

Waste incineration impact for district heat production was studied in the case of a new residential area. The area is served by a district heat network, where the heat is produced mainly in gas-driven standalone heat plants and partly in the municipal waste CHP incineration plant. According to the district heat supplier, their monthly delivered heat distribution is presented in Figure 3, and it can be seen that the share from municipal waste source in this area is on average more than $60 \%$. The carbon footprint is shown in Figure 4.

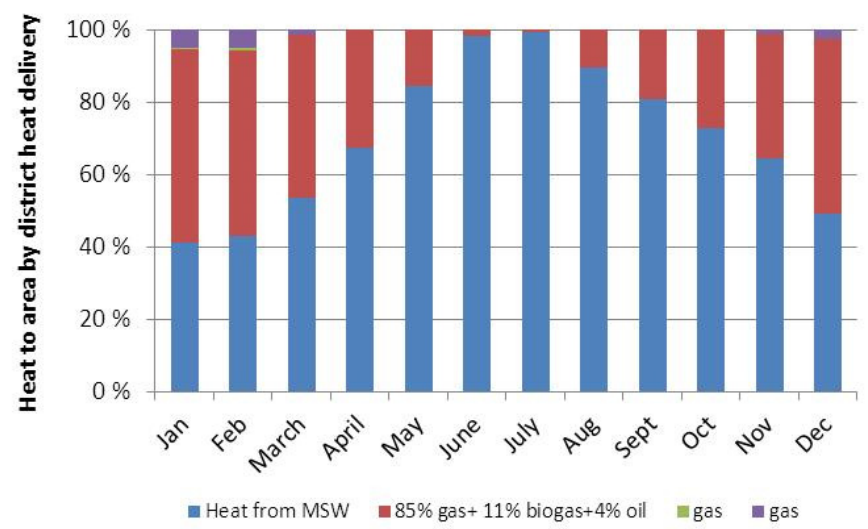

Figure 3: Heat distribution to the area (according to the district heat supplier). 


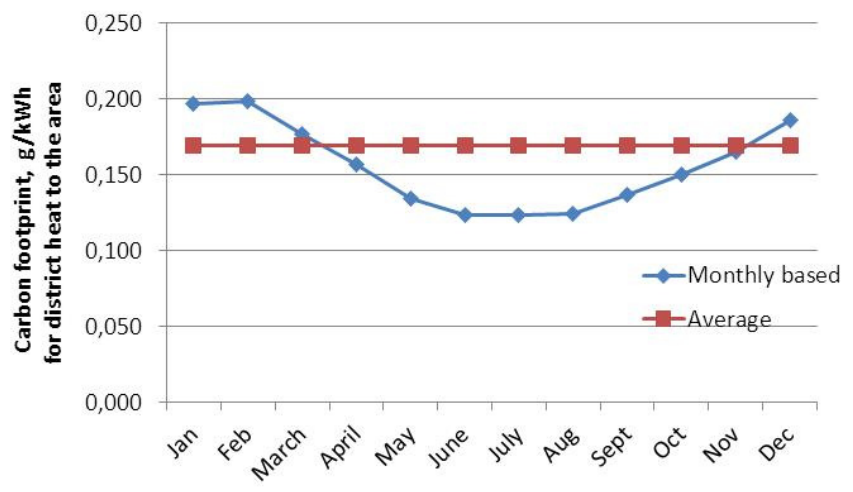

Figure 4: Carbon footprint for district heat production to the studied area (delivery losses are not shown).

The results for the residential area cover 29 family building assessments (product and use stage) for a time period of 25 years. The results also present credits which could be taken into account, because the waste incineration in the CHP plant results in potential raw-material savings at least in recovered metals, avoided methane emissions in the case of landfill disposal, avoided marginal electricity and heat productions. The result for a 25 -year time period is shown in Figure 5; it also takes into account the Finland agreement about greenhouse gas emission reduction in electricity production.

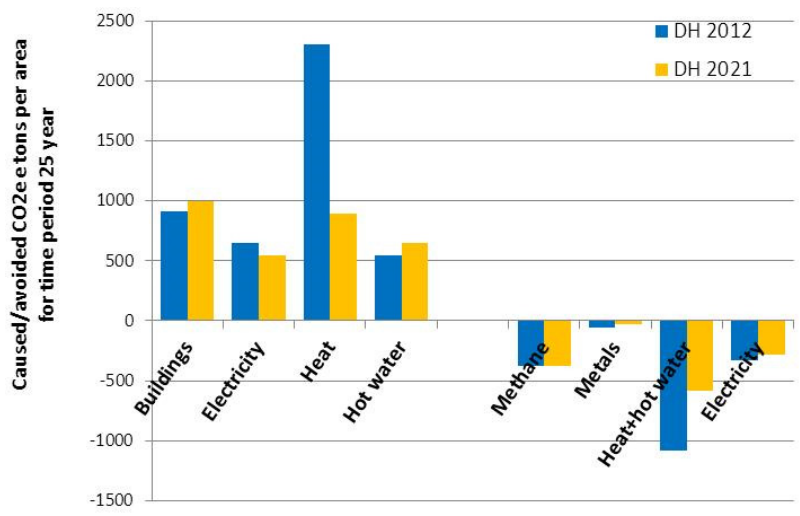

Figure 5: Caused and avoided carbon footprint emissions for a 25-year time period for a residential detached building area in Southern Finland (heat to area is produced by gas driven district heat plant and waste incineration plant). 
The result is also compared to the case where district heat is produced by $100 \%$ natural gas (DH 2012 gas). Total caused and avoided carbon footprint emission is shown in Figure 6.

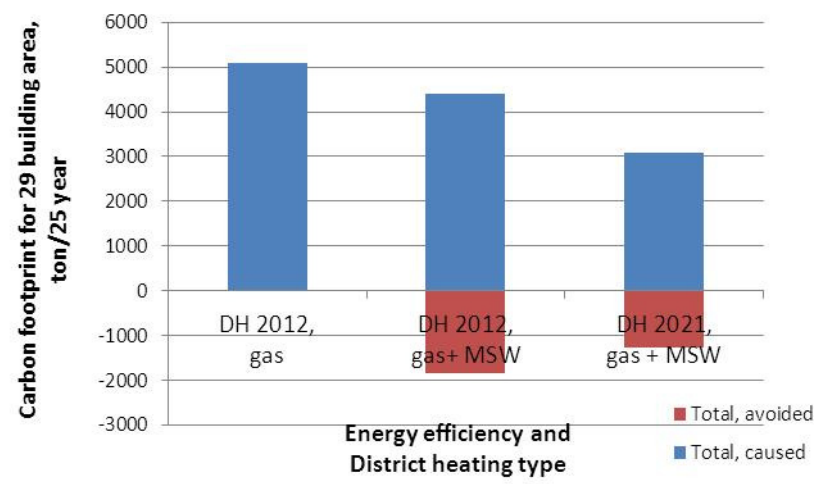

Figure 6: Caused and avoided carbon footprints for studied area.

\section{Conclusion}

Energy performance of the building results from the whole building design; from design structures, material types, use of shadings, from airtightness, indoor air quality, the use of natural lighting, passive heat and cooling elements, heating and cooling systems, but also from the number of renewable energy sources used.

According to the detached residential building area assessment (product stage and operation stage 25-year), the carbon footprint is 5101 tons for current design and for the case where district heat source is natural gas. Carbon footprint for the operational stage depends on the energy production source. When a proportion of district heat is produced by waste incineration, then the result for a 25 -year time perspective is $14 \%$ less, and when energy efficiency of buildings is improved, and then it is as much as $39 \%$ less.

According to the waste hierarchy, waste-to-energy is a second-last option before landfilling, but waste recovery for energy is important in the countries with a long heating season. Using waste as a fuel for heat and electricity production otherwise saves fossil fuels used, but also gives important credits compared to the landfill case. And when the possible credits are taken into account, then the result, compared to the current building (DH 2012, gas), may be improved by as much as $50 \%$. For an energy efficiency solution, the improvement is only $36 \%$. No greater effect is produced because of the decreased energy consumption which influences the waste-to-energy credits.

The Energy Performance of Buildings Directive proposed that nearly zero or very low energy buildings should consume energy mainly from renewable rather than fossil-based sources. To boost the acceptability of waste incineration, the bio- 
based share in mixed waste should be classified as a renewable source. This is not yet the case, but might come into force in the near future.

Finnish district heat production (2012) was 36.7 TWh, and $536 \mathrm{GWh}$ of that was produced from mixed solid waste. This represents only $1.5 \%$ of total heat production, but when new capacity is built in 2016 , the amount of $2038 \mathrm{GWh}$ will already represent almost $5.5 \%$ of total production.

According to the Finnish energy industries, electricity production in Finland (2012) was $67.7 \mathrm{TWh}$, and of that $178 \mathrm{GWh}$ is produced from solid mixed waste. This is only $0.2 \%$ of total electricity production, but when new capacity is built in 2016 , the amount of $678 \mathrm{GWh}$ represents $0.9 \%$ of total electricity production.

The mixed solid waste energy recovery potential in Finland for total energy production is currently not high, but the use of waste as a fuel in energy production replaces fossil fuels that would otherwise be used. As $\mathrm{CO}_{2}$ emission factor for mixed waste combustion is smaller than any fossil-based fuel combustion factor, savings in greenhouse gases could be achieved. The additional savings come from the amount of recovered metals and avoided methane emissions in the case when the waste would be landfilled. This aspect was presented in the case assessment.

\section{References}

[1] Directive 2010/31/EU of the European Parliament and of the Council of 19 May 2010 on the energy performance of buildings.

[2] Finnish Ministry of Environment order no. 4/13, from the $27^{\text {th }}$ of February 2013, (in Finnish).

[3] Finnish Building Code, D3, Energy efficiency of buildings. Guides and recommendations, 2012.

[4] Finnish Statistics Centre and Finnish Energy Industries, Energy year 2012 - District heating (slides in Finnish), http://energia.fi/kalvosarjat/ energiavuosi-2012-kaukolampo (slides in Finnish).

[5] Official Statistics of Finland, Waste statistics. Appendix table 1. Municipal waste in 2012, Helsinki: Statistics Finland (referred: 16.4.2014), http://www.stat.fi/til/jate/2012/jate_2012_2013-11-26_tau_001_en.html.

[6] European Platform on Life Cycle Assessment, Carbon footprint - what it is and how to measure it? Leaflet from 2009. JRC European Commission.

[7] ISO 15804, Sustainability of construction works - Environmental product declarations - Core rules for the product category of construction products. 2012.

[8] Ilmari, software tool, http://www.vtt.fi/sites/ilmari/index.jsp?lang=fi.

[9] Regulation of the Council of State, Finland nr. 179/2012, http://www.finlex.fi/fi/laki/alkup/2012/20120179\#Pidm24000.

[10] Pulkkinen, S., Sinisalo, S., Quality and quantity of household mixed solid waste in the Helsinki metropolitan area 2012 HSY publications 2/2013, pages 44. Helsinki Region Environmental Services Authority, 2013 (in Finnish).

[11] Finnish Statistics Centre, Fuel classification 2014. 
[12] IPCC, Guidelines for National Greenhouse Gas Inventories. Volume 2. Energy. Chapter 2. Stationary combustion, 2006.

[13] Soimakallio, S., Kiviluoma, J. and Saikku, L., The complexity and challenges of determining GHG (greenhouse gas) emissions from grid electricity consumption and conservation in LCA (life cycle assessment). A methodological review. Energy 36(2011), pp. 6705-6713, 2011.

[14] El Hanandeh, A., El-Zein, A., Life-cycle assessment of municipal solid waste management alternatives with consideration of uncertainty: SIWMS development and application. Waste Management 30 (2010) pp. 902-911. 2010.

[15] Finnish Solid Waste Association, Waste incineration capacity growth in Finland, http://www.jly.fi/energia5.php?treeviewid=tree3\&nodeid=5 (referred: 13.04.2014).

[16] Nummela, E. Presentation in Waste management energy seminar, 12 - 13.12.2012, Lahti, Finland.

[17] Software tool IDA, http://www.equa-solutions.co.uk/en/software/idaice.

[18] ELCD database for Natural gas acquisition, EU-27. http://eplca.jrc.ec.europa.eu/ELCD3/processSearch.xhtml. 